\title{
XVII. An account of the Mesembryanthema Ringentia
}

\section{A.H. Haworth Esq. F.L.S.}

To cite this article: A.H. Haworth Esq. F.L.S. (1824) XVII. An account of the Mesembryanthema Ringentia, Philosophical Magazine Series 1, 64:316, 109-111, DOI: $10.1080 / 14786442408644564$

To link to this article: http://dx.doi.org/10.1080/14786442408644564

册 Published online: 29 Jul 2009.

Submit your article to this journal $\sqsubset \pi$

LII Article views: 3

Q View related articles $\asymp$ 
of Bessel's Astronomical Observalions.

Z. D.

\begin{tabular}{|c|c|}
\hline$\varepsilon$ & $=0$ \\
\hline 落 & $+24 \cdot 5+468 \cdot 2 i$ \\
\hline 0.94 & $+20.5+197.3 i$ \\
\hline 0.96 & $-0.8+194.3 i$ \\
\hline 0.97 & $+50.6+340.5 i$ \\
\hline 0.97 & $+0.7+187.6 i$ \\
\hline 0.97 & $+25 \cdot 1+275 \cdot 9 i$ \\
\hline 0.97 & $+54 \cdot 1+523 \cdot 4 i$ \\
\hline $1 \cdot 00$ & $+20.4+522.0 i$ \\
\hline $1 \cdot 01$ & $+1.4+370.3 i$ \\
\hline $1 \cdot 13$ & $+8 \cdot 1+2190 \cdot 0 i$ \\
\hline $1 \cdot 20$ & $+37.9+1337.6 i$ \\
\hline $1 \cdot 20$ & $+170.3+2152 \cdot 6 i$ \\
\hline $1 \cdot 27$ & $-4.3+14100 i$ \\
\hline 1.53 & $+37.4+507.2 i$ \\
\hline $1 \cdot 64$ & $+12.5+177.4 i$ \\
\hline $1 \cdot 80$ & $+34.9+307.5 i$ \\
\hline $1 \cdot 90$ & $+186 \cdot 4+4224 \cdot 5 i$ \\
\hline $2 \cdot 08$ & $+40.7+772.6 i$ \\
\hline $2 \cdot 20$ & $+2 \cdot 7+67 \cdot 9 i$ \\
\hline $2 \cdot 32$ & $+19 \cdot 0+656.0 i$ \\
\hline $2 \cdot 50$ & $-19 \cdot 0+220 \cdot 1 i$ \\
\hline $3 \cdot 60$ & $+13.1+283.4 i$ \\
\hline $3 \cdot 70$ & $-1.8+722 \cdot 3 i$ \\
\hline
\end{tabular}

These equations indicate very clearly a negative value of $i$ : considering the small weight of most of them, their agreement is satisfactory, which, if the exponent $\lambda$ had been neglected, would by no means have been the case. The sum of the equation is $s \quad 0=2007^{\prime \prime} \cdot 0+31745 \cdot 3 i$; from which follows,

$i=-0^{\prime \prime} \cdot 063222$; probable error $= \pm 0^{\prime \prime} \cdot 003981$.

[To be continued.]

XVII. An Account of the Mesembryanthema Ringentia. By A. H. Haworth, Esq. F.L.S. \& c.

To the Editors of the Philosophical Magazine and Journal.

Gentlemen,

HEREUNDER you will receive an improved account of H the sessile-flowered Mesembryanthema Ringentia, which form, perhaps, one of the most interesting divisions of the large genus to which they belong. 
$110 \mathrm{Mr}$. Haworth's Account of Mesembryanthema Ringentia.

Some of these extraordinary plants are now becoming frequent in our collections, and have ever been fancifully likened by gardeners to the chops of animals; and thence called Catchop, Mouse-chop, Tiger-chop, \&c.*; and this from the fantastical idea of each young pair of leaves on the plants bearing some resemblance to the gaping mouths of those wellknown quadrupeds; the ciliating teeth on the margins of the leaves not unaptly representing those of the animals.

The addition of a new species to this singular group has induced me to reconsider the whole, and to forward to you the present communication respecting it for insertion, if you judge it proper, in your Magazine.

This new species, from its long teeth, and following up the allusion of a gaping mouth, I have called lipinum (the Wolf'schop), the substantive rictum being understood, as usual, to accompany the adjectives constituting the specific names throughout the group.

This fine and interesting plant was obligingly communicated to me by my good friend W. T. Aiton, Esq. from the Royal Gardens of Kew, in the year 1823, having been there raised the year before, from Cape seeds, along with a profilsion of other succulent and still more interesting plants; which, through Mr. Aiton's successful exertions, have delighted us with more of the flowery bloom of Africa than we have ever elsewhere seen.

I remain, gentlemen,

Your most obedient servant,

Chelsea, Aug. 1824.

A. H. Haworth.

Mesembryanthemum Linn. Sectio Ringentia Nobis.

\section{Sectionis Characteres.}

Perennia, acaulia, subacauliave: foliis carnosioribus amplexicaulibus semiteretibus, supernè pedetentim dilatantibus, apicem versus triquetro-carinatis, ciliatim ad oras dentatis: floribus magnis pomeridianis sessilibus luteis.

Foliorum juniora paria animalium rictum repræsentant lusoriè.

* Majora: acaulia : foliis lævibus magnis crassis dentibus marginalibus albâ setulâ finientibus, apice cartilagine albo-carinatis.

\section{Specierum Characteres.}

tigrinum. M. (The Tiger-chop) virescens: foliis cordato1. ovatis albo crebrè marmoratis, altissimè ciliatis, suprà

* The Dog-chop (M.caninum) and Fox-chop (M. vulpinum), being scapigerous plants, are removed to the scction Scapigera.

planis. 
Progress of Science respecting Igneous Meteors in 1823. 111 planis.-Mesemb. tigrinum. Nob. in Synops. Pl. Succ. 216, \&c. Bot. Reg. 260.

felinum. M. (The Cat-chop) foliis glaucescentibus parcè

2. altèque ciliato-dentatis, ad lucem creberrimè albopunctatis.-Mesemb. felinum. Nob. in Synops. Pl. Succ. 216, \&c.-M. ringens felinum. Linn. Sp. Pl.698.M. rictum felinum representans. Dill. Elth. f. 230.

lupinum. M. (The Wolf's-chop) foliis glaucescentibus, ciliis 3. marginalibus numerosis altissimis.

Obs. Nova species à Capite Bonæ Spei. Priori simillimum discrepantibus foliis longioribus angustioribus, dentibus duplò numerosioribus, longioreque setulâ finientibus.

$\beta$, foliis viridibus.

** Minora: subacaulia: foliis creberrimè tuberculatim punctatis asperiusculis, quam speciebus tribus prioribus 4 -plo plusve minoribus; dentibus marginalibus brevibus fere absque setulâ finiente.

Foliorum carina apicalis sine cartilagine alba. mustelinum. M. (The Weasel-chop) foliis pellucenter mag4. nipunctatis glaucis, basi internè pustulato-gibbosis. M. mustelinum. Nob. in Suppl. Pl. Succ. 86, \&c.Vespertini flores pungenter suavissimè spirant.

murinum. M. (The Mouse-chop) foliis glaucis turberculato-

5. punctatis, marginibus carinâque apicali ciliato -denticulatis.-M. murinum. Nob. in Synops. Pl. Succ. 217, $\& c$.

Obs. Foliorum dentes longiores numerosiores angustioresque quam in præcedente.

XVIII. A Sketch of the Progress of Science respecting Igneous Meteors and Meteoriles during the Year 1823; including an Account of the principal Phenomena of that Nature observed during the same Period: with Inquiries suggested by those Subjects. By E.W. Brayley, junior, A.L.S., and Member of the Meteorological Society*.

THE arrangement and publication of an annual historical 1 detail of the progress of meteorological science, in its several branches, and of the atmospheric changes and phænomena observed in the various regions of the globe during each successive year, appears to be an object well deserving the attention of the Meteorological Society. A summary of

* Read before the Meteorological Society, May 12, 1824; and published by permission of the Council: with additions by the author.

this 